\title{
4 Unmasking features of the state of the epidemic
}

\author{
What is the uniqueness of the \\ position of older people in \\ Poland?
}

\section{Mariola Racław and Dobroniega Głębocka}

The chapter concerns the situation of older persons in Poland, observed from March 2020 (the so-called first lockdown) to autumn 2020 , i.e., during the emergence and increase in the incidence of the Covid-19 epidemic. Widespread information on the risks related to the threat and mortality from Covid-19 exposed the critical situation of older people as a sub-population at risk of death from the use of comorbidities. We recognise that the introduction of the state of the epidemic in Poland showed real trends of social isolation and social selection of older adults. It results from the primacy of population survival, rooted in society. Disclosed infections and an increase in mortality in nursing homes, the need to regulate medical equipment, isolation from other social groups, justified public health issues, de facto discovered deficits of various groups to protect of older people. Physical protection of life became the cause of the death in the social dimension. In connection with alarming phenomena we pose questions about ways of enhancement of family care potentials and local community care potentials. In this chapter, we analyse the available data and formulate theses regarding the impact of the medicalisation of old age (intensified by the pandemic) on the position of older adults and their social perception, and the consequences of medicalisation for the development of 'silver social work' in Poland.

\section{Introduction}

In Poland, the first case of SARS-CoV-2 was confirmed on March 4, 2020. The state of pandemic was declared in mid-March 2020. As in many countries, it was a shock event for the society in this country also: We understand shock event as a focusing event (...) that has created considerable stress waves in a society (Kawczyńska-Butrym 1996). Kaufmann and colleagues (Kawczyńska-Butrym, 1996) emphasise that these are sudden events, 
relatively rare, with harmful (or judged as harmful) results for society. Such an event has a social impact, causing a wave of shock among politicians, the media and the public. It focuses attention on the problem, which results in the introduction of specific solutions, often with long-term effects and long duration. Sometimes along with the 'turning point', when people feel that the problem has been solved, social tension disappears and the problem is considered as a thing of the parts.

After over a year of the epidemic in Poland, when the country is struggling with growing economic and social problems (Duszyński et al. 2020), it is difficult to indicate which solutions introduced during the pandemic will be maintained in social life and what processes will be initiated or strengthened by them. It seems to us that what is visible and will probably leave lasting results is the consolidation and acceleration of the medicalisation process of old age in Poland with its social consequences. From the outset, the narrative in the public and political spheres was about public health. According to the Polish sociologist Jan Domaradzki, health and life gained the status of superior values during the pandemic ('Coronavirus victims in Poland: What is the average age 2020'). As all government actions were accepted as necessary to protect the population and health of individuals, this was widespread and unquestioned. Their acceptance was related to the experience of a socio-cultural trauma, as a significant number of Poles lost control over the events in their lives.

The politicisation of the epidemic, understood as its introduction to the political game, was associated with a strong medicalisation of various areas of social life. The epidemic per se is related to health and medical issues. In the initial stage of the pandemic, a lock-down was introduced in Poland, the wearing of masks, hand hygiene, physical distance were ordered, remote work was introduced and service points were closed. The public was informed and continues to be informed about infections, illnesses and deaths caused by COVID-19. This coronavirus-induced medication of social life also meant medication of old age in Poland. The thesis of the chapter is that the visible trends in the medicalisation of old age in Poland, which have so far been limited due to the poor condition of public health services and the low income of older Poles, have been significantly reinforced by the emergence of the pandemic. They have also gained strong social legitimacy, stemming from the ideology of protecting older people from the consequences of coronavirus infection. The protection of the older adults has strengthened the tendency towards their social isolation. In our opinion, the experience of the pandemic will contribute to the repositioning of the older adults, medicalisation of their problems and separating them from other social groups.

Another thesis we put forward relates to the impact of the pandemic on the shaping of a new paradigm of working with and for the older adults. The paradigm of socialising people and places, derived from Simmel's understanding of socialisation, makes it possible to see the high-level goals of social work. They are aimed at creating weaker ties of older people in 
their living environments and changing the stereotypical, negative image of older people in Poland. We believe that in the long run, an unintended result of the pandemic, which should be treated as an anticipated reversal effect, will be: (a) the crystallisation of the concept of social work with and for the older adults in Poland, which takes into account the effects of the pandemic, (b) the development of new social practices, resulting from the involvement of social work in building a moral space in the living environment of older people, and (c), increased interest of representatives of helping professions and social politicians in the concept of the caring potential of the family and community (Kawczyńska-Butrym 2008; Wieczorkowska 2018).

\section{The SARS-CoV-2 epidemic in Poland and the older adults: statistical data}

According to official government data in Poland in September 2020 (as of 07.09), since the beginning of the epidemic, over 71,000 infections, over 55,000 recoveries and over 2,000 deaths have been recorded. In September, the current number of patients was almost 14,000. According to the data of the Central Sanitary Inspectorate, in mid-April 2020, in the total number of coronavirus deaths, the share of deaths in the 60-69 age group was about $20 \%$, in the $70-79$ age group - 33\%, and in the $80-89$ age group - almost $30 \%$. The percentages in the remaining age groups did not exceed the value of six percent (Ossowska 2020). These data were confirmed by the Polish Ministry of Health in the subsequent August of the same year. As much as $70 \%$ of the coronavirus fatalities were over 70 years old (Maj \& Skarżyńska 2020). The co-occurrence of additional diseases such as heart disease, diabetes, hypertension, lung and kidney cancer was not without significance. Patients with reduced immunity and those who had organ transplants are particularly vulnerable to infection and death.

Over-representation of deaths in older age categories is a phenomenon that occurs in all countries affected by the pandemic (Kocejko 2020). In addition to many important factors influencing population health data (e.g. availability and quality of health care, behaviour limiting morbidity and mortality), the age structure plays an important role in the analysis of information. In Kocejko’s words,

Age structure (the share of the total population in each age group) alone cannot tell us which countries will be hardest hit in the pandemic but can provide important context in understanding and responding to the crisis. If two countries have the same age-specific mortality rates from COVID-19, the country with an older population would have more deaths per 1,000 people - a higher crude death rate - from the disease than the country with the younger population.

(Kocejko 2020: online document) 
This means that Poland, as a country with an advanced ageing process, will have a relatively high mortality rate due to coronavirus, including in the sub population of older people. In 2018, the share of the population aged 60 and over in the total population was $25 \%$ (Statistics Poland, 2020). Among the sub population of the older adults, about $45 \%$ of people aged 70 and more were recorded. According to the forecasts of the Central Statistical Office, in 2050 the older adults will constitute $40 \%$ of society.

Additionally, the health condition of Polish older adults should be considered. Unfortunately, it is not good. The results show that Poland ranked 88th out of 195 countries when the age-related disease burden rate was taken into account. The age-related disease burden rate is based on the level of disability adjusted life years (DALYS; healthy years lost) per 1,000 adults ages 25 and older (Statistics Poland 2020). This is confirmed by Polish epidemiological data, which indicate multiple morbidity in the older adults (Duszyński et al. 2020). The results of the self-assessment of health made by Polish older adults in 2018 are not optimistic (Statistics Poland, 2020). They rarely indicate good or very good health - only $1.9 \%$ of people over 60 considered their health to be very good, while $23.8 \%$ of older adults indicated "good" as an answer. Sixty-seven percent of people of this age have had long-term health problems or chronic diseases that have (or are expected to continue) for six months or more. In 2018, out of 100 older adults, 69 wanted to receive treatment or testing, of which $87.7 \%$ of them benefited from the test or treatment each time they needed it. Distant appointments, financial difficulties and too long a geographical distance were cited as obstacles to accessing doctors. Additionally, in Poland, we note a low level of development of gerontology in the field of public services. There are 146 geriatric outpatient clinics, with the main locations in three regions: Silesia, Mazovia and Small Poland (Statistics Poland, 2020). Older people in Poland also lack sufficient funds to purchase health services from the private market.

\section{Politicisation of old age in Poland as a precursor to its medicalisation in a pandemic}

In Poland, the Statistics Poland collects data on older people, not only in demographic and epidemiological terms, but also in social dimension. Research on the process of population ageing and the situation of older people is undertaken by researchers from various disciplines and has a long tradition. Those developed from the beginning of the 1990s focus on the aspect of demographic imbalance and the process of population ageing. At the same time, the older adult citizen related policy was conceptualised and started to be implemented, and ageing became a political problem (Duszczyk et al. 2019). The politicisation of the ageing process proceeded with variable intensity and in stages: from retirement demography (ageing and the pension system), through apocalyptic demography (the low fertility trap and the ageing of the population) and institutionalisation of older adult policy (the 
emergence of appropriate government offices dealing with the issue of ageing and old age) to the intensification of such a policy (reform of the pension system, pronatalist program and changes in long-term care) (Duszczyk et al. 2019). The issues of demographic ageing have become a reference point for many specific policies, including health policy, the labour market and social assistance.

As far as social assistance is concerned, it does not have precisely and clearly defined goals of action towards the older adults. In the Act on social assistance in force in Poland (Journal of Laws of the Republic of Poland) there is no provision on guaranteeing social assistance in the event of old age, loneliness and helplessness, which places the older adults in a negative position in relation to representatives of other groups who have guaranteed rights under certain risks. The income criteria adopted, setting thresholds for obtaining financial, material and service benefits for older people, result in a reduction in the number of people receiving social assistance which is not justified in view of the scale of the needs of that group (Sztompka 2002). The current legal regulations do not clearly define the obligations of social services towards the oldest older adults in their living environment (Kaufmann et al. 2016). In addition, the specificity of social work with the older adults (and on their behalf) is defined in the course of supporting the older adults in the environment of their residence and/or stay. It is an expression of the adaptation of values and principles to the institutional and organisational requirements of the implemented practices. The problem of instrumentalising the values and principles of social work with the older adults in social assistance is indicated by research results. In our opinion, the problems outlined above strengthen the processes of politicising old age in the face of many unspecified goals of public tasks. In turn, the politicisation of old age makes it possible to make its medicalisation dynamic in the state of epidemics.

\section{The state of the epidemic and legitimising the medicalisation of old age}

When analysing the population ageing process, Polish social researchers focus not only on its scale and pace, but also on the qualitative aspects of its course. There is evidence that the process of medicalisation of ageing has begun in Poland, but it is not as advanced as in other Western European countries and the USA (Statistics Poland 2018). To medicalise ageing means treating ageing and old age in terms of a disease, not a natural stage in an individual's life (Kanios 2018). It manifests itself in the perception of ageing as a medical problem, which is reflected in various social practices (Kanios 2018). As Nowakowski and Nowakowska conclude, research on old age and ageing undertaken in this approach aims to identify the aetiology of ageing (at the cellular level), which will allow specialists in the field of medicine and pharmacy to intervene in order to inhibit it in specific individuals (Nóżka 
\& Smagacz-Poziemska 2014). Turning old age into a medical problem has consequences in economic, medical and social terms (Golden Book of Good Practices for the Social Participation of Elderly People 2018). Wieczorkowska, based on a review of international literature, indicates the consequences of medicalising old age in the social dimension: strengthening stereotypes about old age, secondary deviation, self-marginalisation and self-blame, dependence on institutions and learned helplessness, lowering the subjective threshold of old age, new nature of the senior-family relationship, escalation of gerontophobia, negation of the possibility of discovering the meaning of natural ageing, ignoring other dimensions of old age, transforming the technological imperative into a moral one (Golden Book of Good Practices for the Social Participation of Elderly People 2018).

The medicalisation process itself is often considered in the context of increasing social control over individuals. It is emphasised that the health care system is intended both to isolate individuals who pose an epidemiological threat and to identify healthy people who are not fulfilling their social roles (Ofiary koronawirusa w Polsce. Jaka jest średnia wieku? [2020]). Social control is supposed to lead to an increase in the self-control of individuals, because health is not only a right of citizens, but an obligation, especially sanctioned during an epidemic. At present, the obligation to estimate health risks and minimise damage to health has been sharpened by legal regulations and by social pressure and ostracism imposed on those who do not listen to government recommendations. In Poland, in social media and news portals, there are heated discussions of outraged citizens who point out the irresponsible behaviour of their compatriots (e.g. the lack of masks in public space), especially young people. Importantly, research shows that people over 55 years of age - compared to other age groups - show the highest degree of obedience to government recommendations and introduced restrictions (Mrowiec 2020a). Despite the emergence of groups denying the existence of a pandemic and rejecting government orders, the discourse of protection, which legitimises the suspension of certain civil liberties, seems stronger than the opposite trend.

In times of a declared pandemic, it seems rational to emphasise taking care of one's own and public health as a civic duty. However, it has current and future consequences for the situation of older people and their social position:

- It seems that focusing the message on the mortality of the old people as a result of SARS-CoV-2 perpetuates a homogeneous image of the older adults (weak organisms, multiple diseases, low physical and mental capacity), who, as passive and defenceless human beings, must be protected. The homogeneity of the perception of a certain category together with a strong belief in the relationship between health, fitness and age form the basis of ageism. In the last decade in Poland, the established stereotype of old people who withdraw from social life 
with age was slowly being deconstructed. We forecast that in the time of a pandemic, this deconstruction process will stop, or perhaps will even be reversed. There may be a chain of feedback loops that will not only restore the status quo, but also change the wider social structure (Trawkowska 2016: 427). It means that not only will the stereotype of a sick and weak senior persist, but there may also be tendencies to isolate the older adults as a method of their effective protection (see recommendations Duszyński et al. 2020: 41). Instead of being included in social life, their institutionalised exclusion will gain social legitimacy.

- Related to the above process is the shift of the subject of tensions in intergenerational conflict. In Poland, due to strong social expectations concerning the support of the older adults by their relatives, this conflict was not very exposed in the cultural dimension. Rather, possible tensions between the categories of young and old people were emphasised against the background of the division of limited public funds allocated to intangible benefits and services. The new dimension of the intergenerational conflict is the biomedical dimension which, along with the strong medicalisation of old age, will point to the social "burden" of old age in the economic dimension (costs of treatment, hospitalisation, social benefits) and due to restrictions on civil liberties (see a statement of the Polish influencer: Scommegna et al. 2020). All manifestations of positive discrimination, e.g. the "hours for seniors" introduced on April 20, 2020 (two hours in retail outlets dedicated only to people over 65) aroused social irritation related to the need to tolerate the privileges of the older-unproductive citizens, despite the generally accepted the ideology of protecting them as vulnerable citizens.

- Exposing health as a superior value that legitimises the restriction of civil liberties also shows a new aspect of citizenship. So far, debates about older adults in Poland have focused mainly on issues of their social citizenship (social benefits, issues of economic status). Along with advanced medicalisation in Western European countries and the USA, and even the genetisation of social life, biological citizenship is revealed, as "the development of genetics makes biology become political" (Domaradzki 2012: 18). It is on the basis of biological criteria that new categorisations of risk groups are created. The language, based on biological categories, which speaks about people, at the same time creates an image of self-aware and responsible patients (...). The goal of the state is largely achieved: individuals become active citizens and not just recipients of biomedical services". (ibidem). So far, the issue of biological citizenship has not been addressed in Poland. We forecast a change in this area and the inclusion of health and fitness as a moral imperative and civic duty. This corresponds to the postulates of active ageing, which assume the reduction of dependence of the older adults as a result of an increase in the average life expectancy in health (LeszczyńskaRajchert 2016: 27). 
The above directions of change seem to be contradictory. However, this is not necessarily the case. Protection and isolation tendencies can be applied en bloc under the state protectorate. At the same time, an alternative image of a healthy older citizen will be promoted, which may be difficult to achieve due to the post-COVID state of the national economy. Nevertheless, the message about protecting oneself against the risk of losing health and fitness as a citizen's duty will be strengthened (Arnoldi 2009). This means that the absence of such actions will be judged as civic negligence and recklessness in relation to the individual regardless of the real possibility of dealing with the risks and uncertainties (Blaxter 2004). In this aspect, the support received in the local environment and the network of institutions, such as social assistance and social work, will be important.

\section{Social work with and for the older adults in Poland after 1990}

In Poland, professional social work with and on behalf of the older adults is in its infancy. After the introduction of the Social Welfare Act (1990) in Poland, which replaced the Social Welfare Act of 1923, not only has there been a significant change in the position of the old people as a beneficiary of social welfare benefits, including social work, but also the very concept of social work with the older adults has been disintegrated. The complexity of the older population in Poland is not conducive to crystallising this concept. Also the use, in the diagnosis and design of care and assistance activities, and in social assistance and in social work for these people, of the typical criteria: gender, age, income, health condition/disability level, family situation, place of residence of the older adults (social assistance home, living with the family or alone) limits or even prevents social work from going beyond the objectives of minimising poverty and alleviating selected consequences of old age in the environment where the older person lives or stays.

This thesis is illustrated by an attempt to organise and describe social work with the older adults, which takes into account the nature of the space for carrying out social work (home space, living environment, institution of 24-hour care) and the degree of independence of the older adults ('dependent/independent seniors'), by Szarota (2015). Independent older adults can benefit from many community-based social support institutions (social welfare centres, counselling centres, senior citizens' clubs, associations and other social organisations (NGOs), third age universities, senior citizens' academies). A dependent senior citizen can use day care facilities, nursing homes, care and treatment facilities, geriatric wards and hospitals and hospices. Services are provided (care, nursing services, neighbourhood care services in the home space) where older adults (dependent and independent) live. The home space may also be a day support centre or assisted housing. Szarota's (2015) proposal clearly indicates that the type of space and the state of independence of an older adult are decisive determinants for the 
entire practice of social work with older adults, of an interventionist and preventive nature.

Another proposal for describing social work with older adults relates to the instruments of a social worker. Models of social work and the method of social work set the typical goals of social work with and for older adults (Kaufmann et al. 2016; Maj \& Skarżyńska 2020): supporting older adults in their development, activating the older adults, preventing marginalisation, improving the quality of life of the older adults, preparation for old age and education for old age. It is assumed that practice patterns in social work, i.e., horizontal models (combining selected, different theoretical approaches in social work) and/or vertical models (combining basic methods of social work) of social work, should serve the achievement of these goals.

After 1990, the belief was systematically expressed that in the Polish context, social work with the older adults and for their benefit should be and is aimed at (Kaufmann et al. 2016):

- $\quad$ professional activity based on principles and working methods specific to the profession of social worker

- a social service integrated with other forms of support for older adults and their families (respite care, neighbourhood care, financial and material benefits, senior citizens' stay at a social welfare home or other 24-hour and day care facilities)

- a social service integrating new and old helping professions that have emerged in the field of assistance, care and activation of the older adults (assistant of an old person)

- a social service that integrates informal social support systems and institutionalised systems, which are set as social policy objectives (including social assistance policies) for older adults and their families. On the basis of regional and local diagnoses, these objectives should be achieved by public and non-governmental social assistance and religious organisations, in cooperation with institutions representing health service, education system, cultural institutions and other institutions important for this phase of life

We believe that the attempts made in the circle of theoreticians and researchers to create models of social work with older adults, based on selected criteria (Kaufmann et al., 2016), as well as standards of social work with older adults developed in cooperation with practitioners (Balon et al. 2011) sanction the status quo in the sphere of social practices. They do not lead to fundamental transformations of the existing models of intervention and prevention, and social practices based on these models, in the institutional space, home and living environment. The main priorities of Polish senior policy: changing the image and situation of older people in society, developing social and care services tailored to the needs of older people, developing an educational offer for old people in areas that meet their needs, 
supporting the development of systemic solutions for the organisation of various forms of learning for older people, including the movement of the Universities of the Third Age, the development of active citizenship of older people, the development of volunteering among older people (Sztompka, 2002), directed the unused potential of "silver social work" in Poland to (Racław, 2011):

- promoting the issue of the rights of older people and disseminating models of successful ageing in the family and in the institutional space,

- development of new specialisations in social work supporting the idea of dignified ageing, such as: oncological social work, social work in palliative care, social work with older and disabled people and their families.

Analyses of practices present in social work with the older adults indicate differentiated use of basic methods of social work in the living space of older people. The predominant methods of assistance for these people and their families are case work and counselling. Small group work, team work and community work models are most commonly used in institutional settings (senior citizens' clubs, day care centres, community centres) (Krzyszkowski 2013). A challenge for social workers and other representatives of the welfare professions is to take preventive and intervention measures in families where there is no interest in the fate of the older adults and where the matter of care in relation to these people is neglected. An attempt by Zofia Kawczyńska-Butrym to define the family's caring potential (Kawczyńska-Butrym 2011; Kijak \& Szarota 2013) was aimed at enriching diagnostic tools in social work with the family, which, in the area of assistance and care for the older adults, is only just becoming institutionalised and is, in comparison with other social work models, the least conceptualised. It cannot be replaced by the transfer of care services and forms of neighbourly assistance that should complement social work with the family. Meanwhile, research shows that these forms of care are territorially dispersed, and at the same time often offered on the basis of non-substantive criteria, which means that they do not reach all people and families in need or satisfy these needs only to a certain extent (Lemke 2010; Szarota 2015).

\section{Could the pandemic help to change the paradigms of social work with and for the older adults?}

After 1990, bottom-up social practices were slowly developing in Poland, which in the area of social work with and for the older adults could be seen as an expression of a change in the attitudes of social assistance workers towards the older adults, as well as a readiness to take up an urgent challenge a change in social attitudes towards the older adults in their living environment and institutional space. In public and media debates, between 1990 and 2013, the ageing of the population as a topic in its own right occupied an 
increasingly important place (Racław 2011), but particularly in the context of changes in the pension system, discussions about the retirement age, the debate about the birth rate and the effects of migration. Significant problems: the health of older adults and neglect in the care of the family, institutional care for older adults as well as the inefficiency and ineffectiveness of local support systems for older adults and families (Sobiesiak-Penszko \& Koziarek 2016), have not, in our opinion, been clearly and consistently brought into the public space. They have become the subject of discourse at a lower level. Internal discourse in social work deals with selected problems of the older adults, their families and the issue of effectively limiting some of the consequences of old age, which are acute at the local level, in the paradigms of care, assistance and activation of the older adults that are relatively better established in social assistance and social work.

The pandemic drew attention to the deficits of public social assistance for older adults and the deficits of non-governmental organisations supporting older adults, their careers and families with the older adults (Krzyszkowski 2013). The research shows that social assistance, non-governmental organisations and local governments during the pandemic struggled with the following problems:

- the need to adapt the functioning of facilities used by the older adults and their careers to the regime and restrictions accompanying the pandemic, which led to changes in the organisation of work of facilities in which gerontological social work is developing;

- the need to develop an appropriate response to the intensity of limitations that have appeared in the everyday life of older people, their families, caregivers in connection with: (a) quarantine and problems that it brought into the lives of people, families and the living environment; (b) a sense of loneliness and the disappearance of social relations among the older adults - clients of social assistance; (c) low digital competences of older adults; (d) difficulties in caring for the older adults, including the provision of care services, clearing access to health and social services, coordinating various services available in the living environment;

- the need to create new practices in helping and caring for older adults, their caregivers and families, in connection with the deterioration of the mental condition of older people, intensification of violence in families and, confirmed by researchers and experts, deterioration of the quality of life of older persons in Poland.

The studies also observed a direct impact of the pandemic on the development of gerontological social work, implemented in social assistance in the living environment of older adults, in social welfare homes and day support centres. The pandemic limited the direct relationships of older persons and their careers with social workers, and thus the possibility of providing emotional support in these relationships, necessary in the event of crises 
experienced by the older adults, their careers and family members. The research showed that social workers experienced three types of difficulties in conducting gerontological social work:

- limitations in interpersonal communication, making it difficult to diagnose the real situation of older adults and to provide emotional support;

- restrictions on access to the most important institutions that provide regular psychosocial and health support, as well as shops and offices;

- coping with the specific reactions of older people and one's own fears resulting from the lack of a sense of security at work in direct contacts with people.

The results of the research conducted by Beata Ziębińska indicate that the pandemic intensified work on a model of crisis intervention as part of gerontological social work conducted in Polish social assistance and created friendly conditions for coordinating support and establishing cooperation in the local environment by representatives of social welfare and volunteers, non-governmental organisations and informal groups. Increased interest in care services on the part of older persons and families with their was observed, as well as intensification of neighbourly help in the living environment of older adults.

We believe that the state of the pandemic clearly highlights some marginalised threads in social assistance and that are important for the emerging concept of social work with and for older adults. The theme of the state of health of Polish older adults, which was systematically raised during the pandemic, may therefore contribute to revitalising the issue of health in social work with and on behalf of older adults in social support institutions and in institutions that educate people for social work. Due to the scale of family involvement in caring for older adults in Poland, as well as the problem of family support noticed by social assistance due to the deteriorating health condition of family members related to care, it is highly probable that local practices will be intensified (in social work schools, social projects) supporting older adults and families with older adults.

Reports of difficulties in providing services in the living environment of older adult citizens (Krasicka 2020), as well as concerns about the safety of service providers and restrictions in the contact between service providers and service users, can be a positive reinforcement in the search for solutions in social work, e.g. in long-term care, in palliative care, and with regard to under-utilised tools in social work, e.g. the case management model for the care of people who are both old and disabled.

It seems to us that the state of the pandemic may strengthen and even intensify the processes of building the identity of social work in the various social support institutions used by older adults. This should take place in occupational therapy workshops, where research shows that the population of disabled people is clearly ageing (Jarosz \& Keneda 2020). 
The potentialand, at the same time, positive consequences of the pandemic for the development of social work with and for the older adults in Poland, as indicated above, lead us to conclude that this difficult situation may accelerate work on the concept of the caring potential of local communities (Wieczorkowska 2018) and the concept of family caring potential (Kawczyńska-Butrym 2008; Kijak \& Szarota 2013), which has begun. Both of these concepts are the starting point for a paradigm shift in supporting the older adults and their family in the local environment. The new paradigm, which stems from the need for greater socialisation of activities to create a senior-friendly social space based on 'dense' relations with and caring for others, stands in opposition to the current understanding of older adults' socialisation as processes of primary and secondary socialisation to the socially expected roles assumed in the ageing process (Nowakowski \& Nowakowska 2010).

A factor conducive to the acceleration of work on the changed paradigm and new concept of social work, and in particular social work with the family and with the community experiencing the consequences of old age, may be observed in studies (Duszyński et al. 2020) in the trend of increasing trust of Polish society in institutions at the local level, which include municipal social welfare centres and family welfare centres. They should therefore have a keen interest in the evaluation of social work. Both concepts can be treated as potential standards against which social work practices should be assessed and evaluated.

We forecast the emergence and further development of new social practices, resulting from the involvement of social work in building moral space in the environment where older people live (Wieczorkowska 2018). This direction has already been noticed, as indicated by good practice projects, in which the theme of intergenerational understanding, integration of generations in education, culture, political activity and voluntary activities, counteracting self-exclusion and isolation of older generations is addressed (Analysis of the activity of occupational therapy workshops in 2008, 2009).

However, the positive consequences of the pandemic that we have noticed: the development of a clearer identity of social work with and for seniors, a coherent concept of this work based on the new paradigm of socialisation of care in the living environment, may be limited or even inhibited. The tension signalled in the relationship between carers and the cared for can be interpreted as traumatic, for both sides, experience of choosing values in a conflicting situation of opposing obligations (between self-protection of the carer and protection of the "fragile" care receiver). At the micro-social level, in the relationship of help and care, tendencies to control and objectify the charges, especially in the conditions of providing care in institutions, towards older people and in poor health, may even intensify. Whereas, older adults using the support of centres and groups in the living environment may be encouraged by representatives of helping professions to greater self-discipline and self-control, which may trigger self-isolation mechanisms among older adults. 


\section{For further discussion...}

Health and taking care of it has become a matter of common concern (Arnoldi 2009) and has been politicised (Blaxter 2004). In the societies of the 21st century, which are described as societies of global risk (Beck 2012), international disasters on a large scale are not always easy to predict, but are inscribed in the specificity of the era. Currently, a health shock event is in the process of being reduced to the technical aspect of risk. Risk factors are estimated for specific population groups. Unlike in earlier eras, death ceases to be accidental and becomes a combination of individual properties (resulting, among other things, from previous negligence), forming the individual's biosocial identity (Leon et al. 2014) and environmental conditions. The pandemic period reinforces the importance of experts who provide guidance based on scientific evidence. However, in Poland, expert discussions and political debates introduce informational chaos, which increases the sense of uncertainty and fear in society (Mrowiec 2020b).

During a pandemic, old routines must be changed. Polish older adults are recommended to limit social contacts (even with relatives) as much as possible and, in the case of necessary contacts, to observe the sanitary regime (Duszyński et al. 2020). As experts from the Polish Academy of Sciences point out, the older adults face a challenge, i.e., 'inventing' a new way of functioning in society, mastering new techniques of communicating with family and friends (e.g. social media), developing new interests (Duszyński et al. 2020). The 'inventing' of a new lifestyle, called preventive practice, becomes the task of a senior citizen with a specific bio-social profile. But will the institutions available in local communities support this process?

Meanwhile, the social work with and for older adults that is being created in Poland faces a double challenge. The first relates to direct practice with and for older adults - how the provision of assistance and care should look like in a situation of requirements and restrictions imposed on the older adults, their careers and institutions providing services in a pandemic situation. Relations at the microstructural level are accompanied by fears and concerns of the providers and receivers of assistance.

The second challenge, present at the meso-structural level, concerns developing a new concept of social work with and for the older adults. In its development, we attribute a significant role to the institutions and organisations dealing with the politicised problem of the pandemic and its effects on the population of older people, who receive various forms of care and assistance from these institutions. There are premises (Duszyński et al. 2020; Analiza działalności warsztatów terapii zajęciowej w 2008 roku., 2009) that routine social work with and for the older adults will be enriched with projects aimed at new goals, creating a more socialised space of local care for the older adults than before. But we cannot rule out another scenario either. In the coming years, it can be expected that the preventive projects developed by local and regional institutions will "replace" projects developed 
from the bottom up by older adults themselves. Our analyses allowed us to formulate the following conclusions:

- The previously observed medicalisation of old age in Poland has intensified during the fight against the COVID-19 epidemic. Life and health became the main value that contributed to the introduction of social isolation as an instrument of protection for the 'weak', i.e., older persons.

- The actions taken by the government in the fight against the pandemic contributed to the consolidation of the social perception of older persons as a homogeneous group, requiring special support and privileges threatening the civil liberties of other social categories.

- In Poland, gerontological social work is only just developing. The shock related to the course of the pandemic made it possible to verify routine care and support practices. It also revealed the need to rethink the relationship between the health care system and social assistance.

- The period of the pandemic fosters the emergence of grass-roots, innovative social practices in the field of assistance and care for older persons and their families in the living environment, strengthening the de-institutionalisation process.

\section{References}

Analysis of the activity of occupational therapy workshops in 2008. (2009). Raport z badania zrealizowanego przez Centrum Badań Marketingowych INDICATOR dla Państwowego Funduszu Rehabilitacji Osób Niepełnosprawnych. Warszawa, maj 2009, https://www.pfron.org.pl/fileadmin/ftp/dokumenty/Badania_i_analizy/ Raport_z_badania_-_Analiza_dzialalnosci_wtz_w_2008_roku.pdf

Arnoldi J., Risk, Polity Press, Cambridge 2009.

Balon K., Rutkiewicz G., Staręga-Piasek J., Stec K., Szmaglińska I., Zielony M., Standard pracy socjalnej z osobą starszą, 2011, s. 9-15, http://www.wrzos.org.pl/ projekt1.18/download/SPS_OS2601.pdf

Beck U., Społeczeństwo światowego ryzyka. W poszukiwaniu utraconego bezpieczeństwa, Wydawnictwo Naukowe Scholar, Warszawa 2012.

Blaxter M., Health, Polity Press, Cambridge 2004.

Domaradzki J., Genetyzacja społeczeństwa. Społeczne konsekwencje nowej genetyki, "Studia Socjologiczne" 2012, Nr 205(2), s.7-26.

Duszczyk M., Lesińska M., Matuszczyk K., Upolitycznienie problemu starzenie się społeczeństwa w Polsce. Teoria i praktyka, WUW, Warszawa 2019.

Duszyński J., Afelt A., Ochab-Marcinek A., Owczuk R., Pyrć K., Rosińska M., Rychard A., Smiatacz T., Zrozumieć COVID-19. Opracowanie zespołu ds. Covid-19 przy Prezesie Polskiej Akademii Nauk, PAN, Warszawa 2020.

Golden Book of Good Practices for the Social Participation of Elderly People editions I-III - Publikacja BRPO, Warszawa 2018.

Kanios A., Postawy pracowników zawodów pomocowych wobec osób starszych, Wydawnictwo Uniwersytetu Marii Curie-Skłodowskiej, Lublin 2018, s. 82-90. 
Kaufmann M., Lewandowski J., Choryński A., Wiering M., Shock events and flood risk management: a media analysis of the institutional long-term effects of flood events in the Netherlands and Poland, "Ecology and Society" 2016, 21(4), 51. https://doi.org/10.5751/ES-08764-210451

Kawczyńska-Butrym Z., Niepełnosprawność - specyfika pomocy społecznej, Wydawnictwo Interart, Warszawa 1996.

Kawczyńska-Butrym Z., Wyzwania rodziny: zdrowie, choroba, niepełnosprawność, starość, Wydawnictwo Makmed, Lublin 2008.

Kijak R. J., Szarota Z., Starość - między diagnozą a działaniem, Centrum Rozwoju Zasobów Ludzkich, Warszawa 2013, s. 42-47.

Krzyszkowski J., Pomoc społeczna wobec starzenia się społeczeństwa polskiego. "Przegląd Socjologiczny" 2013, 62 (2), s. 9-31.

Lemke T., Biopolityka, Wydawnictwo Sic!, Warszawa 2010.

Leon M., Ranci C., Rostgaard T., Pressures Towards and Within Universalism: Conceptualising Change in Care Policy and Discourse, in: M. Leon (ed.), The Transformation of Care in European Societies, Palgrave Macmillan, New York 2014, s. 11-33.

Leszczyńska-Rajchert A., Praca socjalna z seniorami w perspektywie geragogiki, Wydawnictwo Uniwersytetu Warmińsko-Mazurskiego, Olsztyn 2016, s. 79.

Maj K., Skarżyńska K., Społeczeństwo wobec epidemii. Raport z badań, Fundacja im. Stefana Batorego Warszawa 2020.

Marody M., Formatowanie społeczeństwa - o starych i nowych sposobach uspołeczniania działań, in: M. Flis, K. Frysztacki, G. Skąpska, P. Polak (ed.), Co się dzieje ze społeczeństwem?, Wydawnictwo Uniwersytetu Jagiellońskiego, Kraków 2012, s. 145.

Nowakowski M., Nowakowska L., Medykalizacja starości: dylematy i zagrożenia, in: D. Kałuża, P. Szukalski (ed.), Jakość życia seniorów w XXI wieku. Ku aktywności, Uniwersytet Łódzki, Łódź 2010, s. 206-218.

Nóżka M., Smagacz-Poziemska M., Srebrna praca socjalna - adekwatność i potencjał usługi, in: M. Nóżka, M. Smagacz-Poziemska (ed.), Starzenie się. Problemat społeczno-socjalny i praktyka działań, Wydawnictwo Uniwersytetu Jagiellońskiego, Kraków 2014, s. 39-52.

Pawlas-Czyż S., Społeczna rzeczywistość choroby nowotworowej w rodzinie. Profesjonalna praca socjalna w obszarze wsparcia opiekunów nieformalnych osób chorych onkologicznie. Przyczynek do refleksji nad onkologiczną praca socjalną, Wydawnictwo Edukacyjne Akapit, Torun 2018.

Racław M. (ed.), Publiczna troska, prywatna opieka. Społeczności lokalne wobec osób starszych, Instytut Spraw Publicznych, Warszawa 2011.

Sobiesiak-Penszko P., Koziarek M., Jak dobrze mieć sąsiada. Od pomocy sąsiedzkiej do sąsiedzkich usług opiekuńczych. Instytut Spraw Publicznych, Warszawa 2016.

Szarota Z., Uczenie się starości, "Edukacja Dorosłych” nr 1, 2015:s. 54.

Szatur-Jaworska B., Polska polityka społeczna wobec starzenia się ludności w latach 1971-2013, Dom Wydawniczy ELIPSA, Warszawa 2016, s. 333-336.

Sztompka P., Socjologia. Analiza społeczeństwa, Wydawnictwo Znak, Kraków 2002.

Trawkowska D., Potencjał opiekuńczy rodziny - koncepcja i jej konteksty, in: Z. Kawczyńska-Butrym, E. Czapka (ed.), Opieka nad dziećmi i starszymi rodzicami w rodzinach migrujących kobiet, Wydawnictwo Polihymnia, Lublin 2016, s. $17-25$. 
Wieczorkowska M., Społeczne i ekonomiczne konsekwencje medykalizacji starości i starzenia się, „Folia Oeconomica” 2018, Nr 2(334), s. 19-37, DOI: http://dx.doi. org/10.18778/0208-6018.334.02Links used

Jarosz B., Keneda T. (2020). Oldest Areas May Be Hardest Hit: The Importance of Age Structure In Understanding Mortality During the Coronavirus Pandemic, https://www.prb.org/oldest-areas-may-be-hardest-hit-the-importance-of-agestructure-in-understanding-mortality-during-the-covid-19-pandemic/, accessed September 07, 2020.

Kocejko M. (2020). Prawa człowieka mieszkańców DPS to zapomniana sprawa (Opinia), https://publicystyka.ngo.pl/magdalena-kocejko-prawa-czlowiekamieszkancow-dps-to-zapomniana-sprawa-opinia?fbclid=IwAR0CLccASDHEw8s95j0OV83OnMpmyo1qYZP34P2n0wI31MES_DwmLqI2pNc, accessed September 17, 2020.

Krasicka M. (2020). Raport Ministerstwa Zdrowia: kto jest najbardziej narażony na COVID-19?, https://portal.abczdrowie.pl/raport-ministerstwa-zdrowia-ktojest-najbardziej-narazony-na-covid-19, accessed September 17, 2020.

Maj K., Skarżyńska K. (2020). Społeczeństwo wobec epidemii. Raport z badań, Fundacja im. S. Batorego, https://www.batory.org.pl/wp-content/uploads/2020/04/ Badanie-spoleczenstwo-wobec-epidemii-fin.pdf, accessed September 18, 2020.

Mrowiec K. (2020a). Epidemia jest zjawiskiem miejskim - rozmowy socjologów w czasie epidemii (with prof. zw. dr hab. Bogdan Jałowiecki), https://www.ath. bielsko.pl/epidemia-jest-zjawiskiem-miejskim/, accessed September 10, 2020.

Mrowiec K. (2020b). Społeczeństwo ryzyka - rozmowy socjologów w czasie epidemii (with dr hab. Jan Domaradzki), https://www.ath.bielsko.pl/socjolodzy-ospoleczenstwie-ryzyka-rozmowy-w-czasie-epidemii/, accessed September 10, 2020.

Ofiary koronawirusa w Polsce. Jaka jest średnia wieku? (2020). https://www. medonet.pl/koronawirus/koronawirus-w-polsce, ofiary-koronawirusa-w-polsce-jaka-jest-srednia-wieku-, artykul, 26466398.html, accessed September 3, 2020.

Ossowska A., "Wszyscy mamy już dosyć". Sopocka influencerka zabiera głos ws. żółtej strefy (2020). https://esopot.pl/pl/11_wiadomosci/5975_-wszyscy-mamyjuz-dosyc-sopocka-influencerka-zabiera-glos-ws-zoltej-strefy.html, Accessed September 26, 2020.

Scommegna P., Mather M., Kaneda T. (2020). United States Ranks 53 Out of 195 Countries on Aging-Health Problems, https://www.prb.org/older-americansgreater-health-problems-may-make-them-more-vulnerable-to-covid-19s-effects/, accessed September 5, 2020.

Statistics Poland. (2020). The situation of older people in Poland in 2018. https:// stat.gov.pl/en/topics/older-people/older-people/the-situation-of-older-people-inpoland-in-2018,1,1.html, accessed September 27, 2021. 